\title{
The Relationship between Presidential Approval and Media Coverage of First Families: A Content Analysis, 1960-2004
}

\author{
Mandi Bates Bailey and T. Alissa Warters
}

Presidential popularity is often considered a political resource. As a result, polls regularly address presidential approval. Using a content analysis of newspaper articles from the beginning of the Kennedy administration through the conclusion of the first George W. Bush administration, this study examines the relationship between first ladies and first children and presidential approval. Our findings suggest that presidents and first ladies are not necessarily evaluated independently of each other and that the media coverage of presidential children can be both political assets and liabilities to their fathers. Our study, therefore, establishes a foundation and need for future studies pertaining to individuals with close ties to the president.

"Few things are more important to the modern White House than public opinion (Heith 1998, 165)." Several prominent presidential scholars have documented this importance in advancing a president's policy agenda (see for example, Brace and Hinckley 1992; Kernell 1997; Neustadt 1990; Rose 1991). This focus on popularity redefines presidential influence in terms of informal rather than formal powers. Hence, Neustadt (1990) noted that a president's power rests in his ability to persuade based on his reputation, prestige, and ability to bargain, rather than in his formal powers.

Recognizing that popularity is important still leaves the task of determining what variables contribute to the public's evaluation of the president. Such variables may be internal, relating to a president's ability to govern, persuade members of Congress (see Bond and Fleisher 1990 and Neustadt 1990), or appeal directly to the public (Kernell 1997). However, others may be external, such as the economy or dramatic situations that are beyond a president's control. Brace and Hinckley (1992, 10-11) explain this idea of internal and external variables best by stating,

The dramatic events of a term, only some of which a president can control, also affect the polls. ... So when a news story makes comparisons about different presidents' first few months in office, it is combing all these influences - mixing Carter, who took office in bad economic times; with Nixon,

The authors would like to thank Drs. D. Stephen Voss and Christopher A. Cooper for their helpful comment as well as Kimberly O'Donnell, Kellie Collins, and James Kay for their valuable time coding.

MANDI BATES BAILEY is an assistant professor of political science at Valdosta State University. T. ALISSA WARTERS is an assistant professor of political science at Francis Marion University.

The American Review of Politics, Vol. 28, Fall, 2007: 229-247

(c)2007 The American Review of Politics 
who inherited Vietnam War protests; with Reagan, who survived an assassination attempt; with Kennedy, who faced an international crisis and did not survive an assassination.

This study, therefore, attempts to isolate external variables that are all but absent in studies of presidential approval. Specifically, it evaluates whether media coverage of first ladies and first children affects presidential approval. Presidential literature has largely ignored first ladies' ability to affect presidential approval, while it has completely ignored first children's ability to do the same.

Modern presidents have seen their personal lives and the personal lives of their family become a cornerstone of entertainment news. For instance, President George W. Bush's daughters received a great deal of attention related to under-age alcohol consumption, garnering headlines such as "Double Trouble" in the New York Daily News, "Jenna and Tonic" in the New York Post, and "Busted Again in Margaritaville: The President's Twins" in Newsweek. While serving as First Lady, Hillary Clinton certainly received a great deal of media attention as well, particularly when her husband's affair with White House intern Monica Lewinsky became public knowledge. The fascination with the domestic lives of presidents, illustrated by these examples, presents an interesting case for public opinion research. For instance, are first ladies and first children actually meaningful liabilities or assets to the president or are they simply celebrities by association? Additionally, if they are influential, could that influence translate into changes in evaluations of presidential job approval?

This study seeks to determine if the media coverage of first ladies and first children has the ability to impact presidential approval. It begins by developing a theoretical foundation that includes an evaluation of the role of presidential popularity in governing. It then elucidates research perspectives pertaining to first lady studies. An explanation of the empirical methods and statistical techniques follows. Finally the study discusses the implications of the findings, which indicate that first ladies and first children may very well impact presidential job evaluations, and concludes with suggestions for future research.

\section{Theoretical Perspectives}

Brody (1991) states that Americans form their evaluations of presidential effectiveness based on political accounts in the news media. However, news accounts that are political in nature concern more than the intricacies of policies. News accounts featuring the president Americans see are often more personal, assessing character traits and featuring those closest to the president. Studies in political psychology substantiate the notion that 
personal qualities of presidents impact individuals' assessments of presidents (Kinder 1986; Rahn et al. 1990; Sullivan et al. 1990).

Newman $(2003,2004)$ provides evidence of the relationship between character assessment of presidents and corresponding public approval. Assessing character traits through Gallup survey questions involving whether President Clinton "can get things done," whether he is "honest and trustworthy," and whether he "shares your values," Newman (2004) determines that character assessments define public evaluations of the president. President Clinton may be an anomaly considering the personal scandals surrounding his presidency. Analysis of four presidents (Carter through Clinton) provides evidence that integrity assessments affect presidential job approval beyond President Clinton (Newman 2003), however.

Taken together, the literature suggests that a president that is perceived as dignified will likely receive higher approval ratings than one that is not. Thus, as presidential popularity "is said to be a political resource" (Brody 1991; Cornwell 1965; Neustadt 1990), we expect presidents to cultivate this resource and utilize it to excite the governed. Reeves (1991) indicates that President Kennedy did in fact use this resource during the early 1960s when Americans became obsessed with a worship of celebrity and image. The handsome young Kennedy couple supported this image with their two adorable children who were no strangers to the press or photo opportunities in the Oval Office. While Whitcomb and Whitcomb (2000) state that Mrs. Kennedy objected to the press attention given to her children, they also note that President Kennedy felt photographs of his children were good for public relations. Presidents also use their children as surrogates. For instance, President Johnson's daughters made speeches extensively on his behalf during the 1964 presidential campaign (Whitcomb and Whitcomb 2000). However, this is not to suggest that first family members can only positively affect presidential approval. By nature of association, first ladies and first children may also negatively impact a president's popularity. For example, President Ronald Reagan's daughter, Patti Davis, posed a potential liability when she became outspoken about her strained relationship with her father. Similarly, while his relationship with his son was not questioned, President Carter saw the press speculate about his son Chip's marital difficulties, and when Chip Carter and his wife Caron divorced the press speculated about a subsequent romantic relationship (Chanley 2004).

Utilizing presidential wives and children, such as the Kennedy example, provide an illustration Kernell's (1997) notion that presidents appeal to the public for policy support rather than the more traditional method of appealing to Congress. Therefore, it also illustrates the importance of presidential popularity. Presidents do not simply court the public for reelection; they also court the public in the attempt to gain leverage regarding policy 
proposals. For this reason, presidential studies have considered both character and competency in evaluating the public opinion of the president. A president's family may serve as an indicator of his character and the news media allow us to measure that indicator.

Brody (1991) indicated that the news media play a powerful role in evaluating presidents because Americans revise their opinions of the president based on the content of news reports in the mass media. This view is consistent with the notion of individualized pluralism as the news media provide the vehicle through which presidents "go public." Brody $(1991,16)$ is quick to contend that presidents are not "slaves to public opinion"; however, he admits that a positive public evaluation translates into more of an ability to exercise influence. In addition, Brace and Hinckley (1993) indicated that worries about the public relations presidency are slightly overstated, but they did find a degree of support for presidents acting strategically in the attempt to manipulate polls.

\section{Implications of First Lady Research}

... an understanding of the media-White House relationship would not be complete without some analysis of the connection between the first lady and the media. It could be argued that the president's wife, especially in modern times, is one the most powerful, unelected positions in American government. Her influence extends far beyond the fashion spectrum, although designer labels and hairstyles remain a constant source of journalistic fodder.

(Bower 2004, 90)

Few studies assess the political impact of presidential children; however, there is a small, but growing body of literature concerning the political role of first ladies. While Watson (2003) has noted that this scholarship largely lacks a clear theoretical foundation, it does provide direction for extended first lady studies as well as research that seeks to determine the impact of first children on presidential popularity. Moreover, research illustrates that the office of the first lady has evolved both politically and publicly since Eleanor Roosevelt hired a personal secretary and began to utilize the media not only to promote her husband, but also to promote her own issues such as women's rights (Eksterowicz and Paynter 2000).

Cohen $(2000 \mathrm{c}, 575)$ indicates that presidents may view first ladies as "potential political assets," affording them the opportunity to capitalize on their wives when poll numbers go south. This perception of the first ladyship as a potential ace in the hole may give the public the impression that the presidency is a joint-office. This was certainly the case when Bill Clinton began his first campaign for the presidency. Then-Governor Clinton boasted that a vote for him was a vote for Hillary Rodham Clinton as well as for 
himself and Albert Gore, Jr. (Burden and Mughan 1999; Troy 1997; Watson 2003). Clearly, the Clinton strategy cast Mrs. Clinton in a political light prior to ever entering the White House. In turn, she became the first presidential wife to be of continued interest to polling agencies (Burden and Mughan 1999).

Corrigan (2000) evaluated Mrs. Clinton's role in promoting President Clinton's health care reform agenda. Analyzing Gallup polls regarding Hillary Clinton's popularity and 37 public appearances and two major television interviews of the first lady on the subject of health care reform, Corrigan $(2000,158)$ discovered the public found Mrs. Clinton "persuasive when she was testifying as a "mother, wife, sister, daughter, and woman."” However, when she became more of an obviously aggressive political figure these results were less convincing. Therefore, Corrigan concluded that first ladies may be very effective in marshalling support for their husbands' policies; however, they are not so effective in challenging opponents. This finding is especially important because it challenges critics of first lady influence who would believe that the only reason Hillary Clinton was able to provide any sort of influence was because she was appointed head of the health care task force (see discussion of Health Care Reform and Whitewater in Winfield 1997).

The available polling data has enabled scholars to address the relationship between the first lady's popularity and that of the president (Burden and Mughan 1999; Cohen 2000b, 2000c). These findings, while not entirely consistent, illustrate the potential importance of studying first ladies. Burden and Mughan's (1999) work demonstrated that the public evaluated the Clintons independently; however, they noted that their study was ill suited for generalization as extensive polling data on first ladies was simply not available prior to the Clinton Administration. Cohen's (2000b) initial study into public reactions to presidential wives was similarly inconclusive as he failed to demonstrate a causal relationship between the popularity of the first lady and the popularity of the president.

These findings should not immediately discourage future research for two specific reasons. First, recent literature is unable to establish if findings are related only to the Clinton Administrations; they are insufficient to generalize to other presidencies. Second, Cohen's (2000c) admission that measures of popularity are vague suggests the need to look beyond polls to determine the influence of first ladies.

The notion that that first ladies can serve as liabilities and assets is not difficult to extend to presidential children. Similarly, first children are even less likely to have a public persona independent of that acquired by association with their fathers. Furthermore, depending somewhat upon the age of the child, the personality traits as well as the abilities of presidential children 
are easily associated with their parents. More specifically, the younger the child, the more influence parents are likely to have. Therefore, this study seeks to expand our understanding of the public relations presidency by highlighting how media coverage of first ladies and first children affect presidential approval.

\section{Data and Methodology}

We hypothesize that media coverage of first ladies and first children is related to presidential popularity. More specifically, considering Cohen's (2000c, 575) indication that presidents may view first ladies as "potential political assets," and Corrigan's $(2000,158)$ discovery that the public found Mrs. Clinton "persuasive when she was testifying as a "mother, wife, sister, daughter, and woman," we propose two hypotheses. First, we believe that an increase in the frequency with which first family members appear in the news media will result in an increase in presidential popularity ratings. Second, we suspect that first family members can also serve as liabilities as well as assets. Therefore, even though a study such as this cannot establish causation, we hypothesize that while positive media coverage of first family members is related to an increase in presidential popularity ratings, negative media coverage of first family members is related to a decrease in presidential popularity ratings.

Hence, the dependent variable is presidential popularity and the chief explanatory variables are media coverage of first ladies and presidential children. The use of media coverage as a proxy for determining opinions toward first ladies and first children was noted above. Additionally, two specific reasons merit this use. First, unlike presidential popularity, there are no polls available to ascertain opinions about presidential children and related first lady research is limited to a few studies that fail to incorporate a range of presidencies. In fact, first lady research is largely confined to the Clinton administrations (Burden and Mughan 1999; Cohen 2000a, 2000b). Further, media commentary affects presidential popularity (Brace and Hinckley 1992). Therefore, evaluating media coverage of first ladies and first children is an appropriate means of testing this study's hypotheses.

The sample consists of all presidential administrations beginning with Kennedy and ending with George W. Bush's first term. We have selected Kennedy as the starting point because his was a highly publicized administration and his White House tenure began the age of the media presidency (White 1961). Additionally, practical concerns such as data collection, coding, and time constraints prevent the use of previous administrations. Furthermore, we have chosen to conclude with the first George W. Bush administration because the second administration of George W. Bush is not yet complete. 


\section{Explanatory Variables}

This study utilizes a content analysis of newspaper articles to determine the influence of first wives and first children. The results of the content analysis are compared to presidential job approval data. This analysis is limited to news articles from the New York Times. We are not concerned that using only the New York Times will compromise our research because Page and Shapiro (1986) indicate that the coverage contained in the widely circulated paper tends to be representative of American newspapers in general. A total of 1672 articles were collected by searching the news section of the New York Times for references to first ladies and first children by their names. Other sections of the paper were omitted from this analysis.

Three students were trained to code the New York Times articles (see Appendix for the instrument). We constructed the instrument to consider story length, specifically if the story was a full article or merely a "blurb" (consisting of two paragraphs or less), and placement, whether the article was a cover story or located elsewhere in the paper. Additionally, the codesheet addressed story frames, story themes, and the tone of the articles.

The story frame variables are concerned with the foci of the stories or simply the various targets addressed in each article. Specific foci include the president, the first lady, first children, and campaign. While this study primarily concerns presidential children and first ladies, a review of the data revealed that several articles addressed the first family as a unit rather than individuals. Similarly, news stories addressing other extended family members often contained references to first children and first ladies. Therefore, we created an extended family variable addressing the president's family from the "other" measure in the instrument. Whereas the previous foci variables (the president, the first lady, first children, etc.) are dichotomous, the extended family variable is not. It is assessed in terms of no focus on the entire first family or an extended family member, the entire first family, the president's family, and the first lady's family. Furthermore, history suggests that other family members can impact evaluations of presidents. For instance, Kelley (2004) investigates media coverage of Presidents Carter and Clinton's brothers to find that Clinton was successful in separating his brother's addiction and problems with the law from his administration. President Carter, however, was less successful in keeping his brother's indiscretions from impacting his reputation, allowing the media to shape unflattering images of his family and administration (Kelley 2004). Separate variables are required for each of these measures because any story may have multiple foci.

The frame, or angle a story takes, should not be confused with the subject matter of the story. Story theme variables address this content. 
Dichotomous variables, coded for absence and presence, represent various story themes such as the domestic life of the president, personal stories of the first lady and first children, and public opinion toward the president. Additionally, we created an "official responsibilities" variable from an "other" variable after finding the theme present in several of the articles. Much like story frames and the following discussion of tone, story themes require several variables because they are not mutually exclusive.

The tone variables offer evaluation of news coverage. These variables address the presentation of the president, his administration, the first lady, presidential children, campaigns, and the coder's overall impression. An "other" tone variable was also included to capture the tone of additional subjects not included in the previous list. Each tone variable, with the exception of "overall impression," is assessed as either "not applicable," "positive," "neutral," or "critical." Because each article must generally fit into a positive, neutral, or negative categorization, the "overall impression" variable does not include a "not applicable" response. Finally, we include a frequency variable, which addresses the number of articles in a given month that contained any reference to the first lady or first children. ${ }^{1}$

Additionally, we have included a number of control variables in the attempt to avoid any omitted variable biases. Brody (1991) indicates that analyses of this kind should employ valence issues because there is "no disagreement in the public" as to whether these issues are desirable. In other words, there are certain elements of the political climate that should be considered when evaluating presidential popularity. Therefore, we control for issues that concern the vast majority of citizens. Such controls include measures of inflation and unemployment (gathered from U.S. Department of Labor: U.S. Bureau of Labor Statistics). Economics matter; people prefer to keep costs and unemployment as low as possible. Therefore, it is reasonable to expect that evaluations of the president may vary based on these criteria. However, we must be careful in including these variables by controlling for trends. Therefore, we consider monthly increases and decreases in both inflation and unemployment rates rather than the monthly rates themselves.

Similarly, we include measures that control for media-induced trends. Brody (1991) refers to these trends as "crises of confidence." For instance, wars and scandals may affect people's perceptions of the president and his ability to govern. We, therefore, include a conflict variable that considers international conflicts (e.g., The Vietnam War and Operation Desert Storm), and a scandal variable that addresses events such as Reagan's involvement in the Iran-Contra fiasco, Watergate, Ford's pardon of Nixon, and the various scandals in which former President Clinton found himself involved. Moreover, we include a variable recognizing the "honeymoon period," or 
the first year of a president's term in which he tends to enjoy more favorable media coverage. Each of these variables is dichotomous.

\section{Dependent Variable}

Data representing presidential popularity are readily available. We obtained the job approval data from the Gallup Poll Reports. This section addresses the use of the Gallup surveys first by considering the primary advantage of their use, their sampling process, and finally the question wording.

We selected Gallup polls primarily for the sake of consistency. The polls date back prior to the Kennedy administration and the question wording is nearly identical across administrations. Respondents within these samples specifically answered the following or a very similar question: "Do you approve or disapprove of the way President $X$ is handling his job as President?" Possible answers were "approve," "disapprove," and "no opinion." This ensures that variation across administrations is not the result of question wording.

An additional advantage to using the Gallup polls is sample selection. The surveys are not strictly random. They are stratified by region and adjusted based on Census Bureau data. This process reduces the likelihood that certain segments of the population will be over or undersampled.

As advantageous as these data are, they are slightly ill suited for this study. This is primarily because the surveys were taken at random times. They were not weekly or even consistently monthly during earlier administrations. To compensate for this problem, we weighted the entire data set, including the independent variables as well as the dependent variable, by monthly means, recognizing that this process yields several observations with missing data. Similarly, in addition to models that address only the available Gallup data, we include analyses containing estimated approval ratings for months that are absent from the previous and following months in the attempt to eliminate as many observations with missing data as possible. ${ }^{2}$

Using monthly means with the Gallup data requires using monthly means with data collected from the content analysis. Therefore, the unit of analysis is the monthly mean rather than the individual newspaper articles. This approach is advantageous because it takes into consideration the erratic data collection in the early Gallup polls while utilizing as much of the data collected as possible. Moreover, because we use the "frequency control" we are taking into consideration any concern about certain months being based on one or two articles (particularly in earlier administrations where references to or articles about first ladies and children were comparatively scant compared to later administrations) while others may be based on upwards of thirty. 


\section{Results}

Prior to elucidating the method of analysis utilized in this study and our subsequent findings, we must first caution the reader. While our study seeks to provide evidence of a relationship between media coverage of the first family and presidential popularity, it does not establish causation. However, our study does indicate a strong need to evaluate press coverage of the first family because it reveals a relationship between that coverage and presidential popularity.

Our statistical analyses consist of simple ordinary least squares regressions. These analyses were conducted using four different data sets. Each data set represents either the Kennedy through Reagan era or the George H.W. Bush through George W. Bush era and either contains estimates for several missing months or does not contain these monthly estimates. We included the latter approach for an obvious reason: specifically, while we can speculate that the average approval rating for a month will resemble the mean of the adjacent months, we cannot be sure this is the case. Therefore, by including analyses that contain these estimates as well as analyses that do not we assure that our results are not an artifact of mispecified monthly approval estimates. The reader is advised, however, that models that do not include monthly estimates necessarily provide fewer observations.

Our reasoning for the separation of the data into two periods is not quite so logical. Rather, this decision was based solely on necessity. During our coding process the search engines we were using (primarily Lexis Nexis; however, through Reagan we used Proquest as well) changed. Fortunately for us this occurred between administrations; however, when we repeated some earlier searches to determine how to address the system changes we did not receive as many articles as we did with our initial searches. For this reason, we decided not to collapse the data sets even though the dependent variable was measured in the same fashion and the same coding process was employed. Ironically, even though we suspect the searches for the final three administrations to be slightly less comprehensive, the searches for the George H.W. Bush through George W. Bush era produced a total of 1,061 articles mentioning the names of first ladies and first children as compared to 611 articles in the Kennedy through Reagan era. Additionally, the Kennedy through Reagan dataset suffers from a large amount of missing observations because consistent polling information for the entirety of that time period is simply unavailable. Contrastingly, more consistent Gallup polling data are available for the latter time period. Moreover, we chose to work with the two periods of data because while we are relatively certain we cover all New York Times articles mentioning first ladies and first children (in the general news section of the paper), the change in the search engine prevents us from being 100 percent sure. 
For the sake of brevity, we will not elaborate the complete results of each analysis here. Rather we focus on the primary explanatory variables of interest instead of reporting insignificant findings that are not of paramount concern to this study. The remainder of this section illustrates the results of these analyses, which indicate varying degrees of support for our hypotheses and point to news coverage of presidential family members influencing presidential approval.

These findings clearly contradict previous first lady studies that indicate the American public evaluates the president and the first lady independently. Our analyses reveal an apparently statistically significant relationship between press coverage of first children and first ladies and presidential approval as well as a statistically significant relationship between additional family members and presidential approval in some cases. These relationships are particularly evident regarding news that is not necessarily about these relatives, but only contains a frame related to them. We have illustrated this relationship in Table 1.

Clearly, whether one addresses Kennedy through Reagan or George H.W. Bush through George W. Bush, statistically significant relationships exist between first family members and presidential approval. These relationships are positively related to presidential approval in each of the models. The relationship between foci on first ladies and/or first children and approval of the president were not statistically significant in the models considering the Kennedy-Reagan era, however. In this instance, the additional family members positively impacted presidential approval. In other words, prior to 1989 when news stories featured members of a president's family other than his wife and children (e.g., siblings or parents) his approval rating would benefit.

In our Kennedy through Reagan analysis as well as our George H.W. Bush through George W. Bush analysis we see positive relationships between foci on first ladies and first children and presidential approval. However, these relationships are not statistically significant in the Kennedy through Reagan analysis while they are for the George H.W. Bush through George W. Bush era. Hence, after January of 1989 when New York Times articles featured first ladies or first children presidents were more likely to witness an increase in their approval ratings.

The statistical significance of these foci variables varies between the .1 and .01 levels. Additionally, the reported r-squared statistics indicate that the variables included in each of the models explain between 23 percent and 41 percent of the variation in presidential approval. None of the foci variables reached statistical significance in the George H.W. Bush-George W. Bush model that did not contain monthly estimates, however. 


\section{Table 1. OLS Regression Model of Presidential Approval and Family-Related Media Coverage: News Foci}

\begin{tabular}{|c|c|c|c|}
\hline $\begin{array}{l}\text { Independent } \\
\text { Variables }\end{array}$ & $\begin{array}{l}\text { Kennedy-Reagan } \\
(01 / 1961-01 / 1989) \\
\text { With Monthly Est. }\end{array}$ & $\begin{array}{c}\text { Kennedy-Reagan } \\
\text { (01/1961-01/1989) } \\
\text { No Monthly Est. }\end{array}$ & $\begin{array}{c}\text { George H.W. Bush- } \\
\text { George W. Bush } \\
(01 / 1989-01 / 2004) \\
\text { With Monthly Est. }\end{array}$ \\
\hline First Children & $\begin{array}{c}4.18 \\
(3.17)\end{array}$ & $\begin{array}{c}0.29 \\
(3.66)\end{array}$ & $\begin{array}{c}6.65^{*} \\
(3.79)\end{array}$ \\
\hline First Lady & $\begin{array}{c}3.86 \\
(3.16)\end{array}$ & $\begin{array}{c}1.41 \\
(3.59)\end{array}$ & $\begin{array}{l}6.25^{* *} \\
(3.19)\end{array}$ \\
\hline Additional Family & $\begin{array}{l}24.61^{* * *} \\
(6.24)\end{array}$ & $\begin{array}{l}23.07 * * * \\
(6.59)\end{array}$ & $\begin{array}{c}1.25 \\
(1.17)\end{array}$ \\
\hline Article Length & $\begin{array}{c}-.92 \\
(2.72)\end{array}$ & $\begin{array}{c}1.05 \\
(3.22)\end{array}$ & $\begin{array}{l}-2.38 \\
(4.18)\end{array}$ \\
\hline Article Placement & $\begin{array}{l}-4.68 \\
(3.65)\end{array}$ & $\begin{array}{l}-4.77 \\
(4.45)\end{array}$ & $\begin{array}{c}6.65 \\
(6.35)\end{array}$ \\
\hline Overall Article Tone & $\begin{array}{c}.70 \\
(1.55)\end{array}$ & $\begin{array}{c}-.51 \\
(1.82)\end{array}$ & $\begin{array}{c}2.12 \\
(1.85)\end{array}$ \\
\hline Frequency & $\begin{array}{l}-.24 \\
(.25)\end{array}$ & $\begin{array}{l}-.09 \\
(.28)\end{array}$ & $\begin{array}{l}.24 \\
(.18)\end{array}$ \\
\hline Honeymoon & $\begin{array}{l}10.81 * * * \\
(1.67)\end{array}$ & $\begin{array}{l}11.10 * * * \\
(1.91)\end{array}$ & $\begin{array}{l}3.11 \\
2.01\end{array}$ \\
\hline Scandal & $\begin{array}{l}-9.15 * * * \\
(2.36)\end{array}$ & $\begin{array}{l}-10.23 * * * \\
(2.65)\end{array}$ & $\begin{array}{l}-4.57 * * \\
(1.91)\end{array}$ \\
\hline Conflict & $\begin{array}{c}.41 \\
(2.04)\end{array}$ & $\begin{array}{c}2.29 \\
(2.32)\end{array}$ & $\begin{array}{l}8.12 * * * \\
(2.23)\end{array}$ \\
\hline Inflation Lag & $\begin{array}{c}3.25^{*} \\
(1.80)\end{array}$ & $\begin{array}{c}1.89 \\
(1.87)\end{array}$ & $\begin{array}{l}-3.45^{*} \\
(1.88)\end{array}$ \\
\hline Unemployment Lag & $\begin{array}{c}.33 \\
(3.72)\end{array}$ & $\begin{array}{l}-2.57 \\
(4.44)\end{array}$ & $\begin{array}{r}-1.47 \\
6.22\end{array}$ \\
\hline$r^{2}$ & 0.39 & 0.41 & .23 \\
\hline
\end{tabular}

Much like news stories containing a focus on first family members yield significant results, news stories about first ladies and first children do as well. Table 2 contains these findings that illustrate positive relationships between news coverage about first ladies (the first children theme is slightly over the .1 threshold) and presidential approval. However, in this case the 
variables of interest fail to reach statistical significance in both of the Kennedy through Reagan models and in the George H.W. Bush-George W. Bush model that does contain monthly estimates. Additionally, we must also note that because we did not search for articles about additional family members, such articles were originally coded as "other." Ultimately, we did not find enough of these observations to create a variable reflecting stories that were primarily about additional family members.

Table 2. OLS Regression Model of Presidential Approval and Family-Related Media Coverage: News Themes

\begin{tabular}{|c|c|}
\hline Independent Variables & $\begin{array}{c}\text { George H.W. Bush-George W. Bush } \\
(01 / 1989-01 / 2004) \\
\text { With Monthly Estimates }\end{array}$ \\
\hline First Children & $\begin{array}{c}4.82 \\
(3.59)\end{array}$ \\
\hline First Lady & $\begin{array}{l}5.70^{* *} \\
(2.68)\end{array}$ \\
\hline Article Length & $\begin{array}{l}-2.34 \\
(4.19)\end{array}$ \\
\hline Article Placement & $\begin{array}{c}7.07 \\
(6.36)\end{array}$ \\
\hline Overall Article Tone & $\begin{array}{c}2.76 \\
(1.83)\end{array}$ \\
\hline Frequency & $\begin{array}{c}.22 \\
(.18)\end{array}$ \\
\hline Honeymoon & $\begin{array}{c}2.39 \\
(2.03)\end{array}$ \\
\hline Scandal & $\begin{array}{l}-4.88 * * * \\
(1.90)\end{array}$ \\
\hline Conflict & $\begin{array}{l}10.23 * * * \\
(2.06)\end{array}$ \\
\hline Inflation Lag & $\begin{array}{l}-2.81 \\
(1.87)\end{array}$ \\
\hline Unemployment Lag & $\begin{array}{c}1.34 \\
(6.00)\end{array}$ \\
\hline$r^{2}$ & .23 \\
\hline \multicolumn{2}{|c|}{ Significance at $* .1, * * 05, * * * .01$; Standard errors in parentheses } \\
\hline
\end{tabular}


Table 3. OLS Regression Model of Presidential Approval and Family-Related Media Coverage: Tone

\begin{tabular}{lc}
\hline & $\begin{array}{c}\text { George H.W. Bush-George W. Bush } \\
(01 / 1989-01 / 2004) \\
\text { With Monthly Estimates }\end{array}$ \\
Independent Variables & $1.47^{*}$ \\
First Children & $.85)$ \\
& 1.81 \\
First Lady & $(1.39)$ \\
& .62 \\
President & .90 \\
& -2.09 \\
Article Length & $(4.14)$ \\
& 6.27 \\
Article Placement & $(6.24)$ \\
& .10 \\
Frequency & $(.20)$ \\
& 2.75 \\
Honeymoon & $(2.00)$ \\
Significance at $* .1, * * 05, * * * .01 ;$ Standard errors in parentheses \\
Scandal & $-5.61 * * *$ \\
& $(1.96)$ \\
Conflict & $9.39 * * *$ \\
& $(2.01)$ \\
& $-3.04 *$ \\
& $(1.86)$ \\
& 1.22 \\
& $(6.06)$ \\
& .22 \\
& \\
&
\end{tabular}

The focus and theme variables analyzed above provide support for our hypothesis that coverage of first families is positively related to presidential approval. We, on the other hand, found only a degree of support for our hypothesis regarding tone. Prior to addressing this finding, we must interject that an additional control was inserted into the models testing the relationship between the tone of news accounts featuring first family members and presidential approval. These models required that we control for the tone in which the president is presented in the same articles. While including this 
control resulted in the loss of some observations, it is important to realize that positive coverage of first family members may not negate negative coverage of the president in the same story and vice versa. The overall tone variable is excluded in this model.

Surprisingly, while the various family variables we introduced produced significant findings, the tone in which first family members was presented only appears to be significant in one instance. More specifically, as shown in Table 3, the tone of the first children is positively related to presidential approval at the .1 level only in the George H.W. Bush-George W. Bush analysis that contained the estimated approval data for certain missing months. Therefore, positive coverage of presidential children can assist the president while negative coverage of first children may deflate their fathers' approval rating. The r-squared statistic in this model explained 22 percent of the variance.

Our analyses reveal that first family members may indeed serve as potential political assets and liabilities to presidents. However, our findings are not consistent across all models. With tone we see a statistically significant positive relationship between the manner in which first children are presented in the news and presidential approval only during the George H.W. Bush, Bill Clinton, and George W. Bush administrations and only in the model that estimates certain missing monthly approval ratings. Hence, while positive coverage of first children may lead to greater support for the president, we cannot be too confident of this finding.

Additionally, while the strength of the relationships varies, we still see statistical significance regarding news stories that feature first ladies and first children. These findings present an interesting avenue for future research considering they contradict previous studies that suggest people evaluate the president independent of the first lady (Burden and Mughan 1999; Cohen 2000b, 2000c).

\section{Implications and Conclusions}

Most of the vast literature on presidential approval focuses on the impact of economic conditions and major international and domestic events. Consequently, our understanding of character's role in these evaluations remains limited.

(Newman 2004, 438)

This study has explored factors contributing to character. It has articulated the importance of presidential popularity while the statistical analyses employed illustrate the importance of studying first ladies' and first children' as well as other family members' influence on presidential approval. Significant relationships between these family members and presidential 
approval indicate their roles in policymaking. Geer $(1996,37)$ articulated a related point stating, ". . . concerns about policy take second place to maximization of public support. The reason for this particular ranking is that politicians need the public's support before they can effectively pursue policy." Waterman, Wright and St. Clair (1999) underscore this point by indicating that managing presidential image in the media is of essential importance to a president's policy agenda.

Much like Bagehot (1873) indicated that the efficiency of the British monarchy is dependent upon its dignity, the president's ability to gain support for his policy agenda is dependent upon his popularity. Therefore, in order to better convince his party, Congress, and the country as a whole of the merits of his policy proposals, the president needs to bolster his image. Moreover, evidence suggests that greater public support for a president translates into greater congressional support (Kernell 1997).

This study does not imply that presidential success is entirely dependent upon popularity or even that a president's policy proposals are doomed to fail if his approval rating is low. Rather, it underscores the importance of popularity and calls attention to variables that are largely or entirely absent in the current literature.

The analyses presented above suggest that presidents and first ladies are not necessarily evaluated independently of each other, as previous research has implied and that presidential children too can be both political assets and liabilities to their fathers. ${ }^{3}$ Moreover, this study indicates a need for continued research. For instance, the issue of tone needs further exploration. As discussed above, this study revealed only one instance in which tone mattered and conventional wisdom would seem to indicate that tone should be important. Additionally, this study taken together with Han's (2004) comparative analysis of first sons and first daughters, which suggests that first daughters receive more media coverage, directs future studies to investigate whether first sons and first daughters have differing impacts on presidents' popularity.

Finally, much like many media studies, we can only suggest relationships between these first family variables and presidential approval. We cannot establish causation. In spite of this shortcoming, we feel this study has merit for two primary reasons. First, our findings not only contribute to the small body of first lady literature, they also establish a foundation and need for future studies pertaining to additional individuals with close ties to the president. More specifically, because we illustrate that a president may be evaluated by those closest to him, perhaps research should not end with families and political allies. Rather, maybe it should also extend to personal friendships and professional acquaintances. Secondly, our study contributes 
to the foundation set by Newman $(2004,2003)$ by moving beyond economics to explain presidential approval.

\section{APPENDIX}

\section{Coding Sheet: Newspaper Coverage of First Families}

1. New York Times

Coder:

2. Date:

3. Length:

A - Full Article B - Blurb

4. Placement of Story:

A - Cover Story B - Remainder of Paper

5. Title:

6. Story Frames:

A - Focus on First Child, Name:

B - Focus on President, Name:

C - Focus on First Lady:

D - Campaign:

E - Other:

7. Story Themes:

A - Domestic Life of President

B - Personal Story of First Child

C - Personal Story of First Lady

D - Public Opinion Toward President

E - Other:

8. Tone of the Coverage

A - President (Favorability)

Positive

Neutral

Critical

B - Administration

Positive

Neutral

Critical

C - First Child

Positive

Neutral

Critical

D - First Lady

Positive

Neutral

Critical
E - Campaign

Positive

Neutral

Critical

F - Other:

Positive

Neutral

Critical

G - Overall

Positive

Neutral

Critical 


\section{NOTES}

${ }^{1}$ We further included an interaction term consisting of frequency and tone (frtone $=$ frequencyXtone); however, this variable did not prove to be statistically significant in any of the models we ran. For this reason we are not reporting models that contained the interaction term. The term had very little impact on any model. However, it did inflate the r-squared statistic in certain cases. Thus, by not including the term our results are actually more conservative in some instances.

${ }^{2}$ Note this process can only be employed when one month is missing from a series. We are unable to estimate values for series of missing months.

${ }^{3}$ This suggests that earlier studies indicating that the public evaluated the president and the first lady independently were not necessarily incorrect. Rather, their results can simply not be extended beyond the Clinton White House.

\section{REFERENCES}

Bagehot, Walter. [1873] 1993. The English Constitution. London: Fantana.

Bond, Jon R., and Richard Fleisher. 1990. The President in the Legislative Arena. Chicago: University of Chicago.

Bower, Carol Lynn. 2004. The Media in their Midst. In Life in the White House: A Social History of the First Family and the President's House, ed. Robert P. Watson. Albany: State University of New York Press.

Brace, Paul, and Barbara Hinckley. 1992. Follow the Leader: Opinion Polls and the Modern Presidents. New York: Basic Books.

Brace, Paul, and Barbara Hinckley. 1993. Presidential Activities from Truman to Reagan: Timing and Impact. Journal of Politics. 55:382-398.

Brody, Richard A. 1991. Assessing the President: The Media, Elite Opinion and Public Support. Stanford, CA: Stanford University Press.

Burden, Barry C., and Anthony Mughan. 1999. Public Opinion and Hillary Rodham Clinton. Public Opinion Quarterly 63:237-250.

Chanley, Virginia A. 2004. The Carter White House: The Public and Semiprivate Lives of the First Family. In Life in the White House: A Social History of the First Family and the President's House, ed. Robert P. Watson. Albany: State University of New York Press.

Cohen, Jeffrey E. 2000a. The Polls: The Components of Presidential Favorability. Presidential Studies Quarterly 30:169-177.

Cohen, Jeffrey E. 2000b. The Polls: Public Attitudes toward the First Lady. Presidential Studies Quarterly 30(2):374-381.

Cohen, Jeffrey E. 2000c. The Polls: Public Favorability toward the First Lady, 19931999. Presidential Studies Quarterly 30:575-585.

Cohen, Jeffrey E. 2000d. The Polls: Change and Stability in Public Assessments of Personal Traits, Bill Clinton, 1993-99. Presidential Studies Quarterly 31:733-741.

Cornwell, Elmer, Jr. 1965. Presidential Leadership of Public Opinion. Bloomington: Indiana University Press.

Corrigan, Matthew. 2000. The Transformation of Going Public: President Clinton, the First Lady, and Health Care Reform. Political Communication 17:149-168. 
Eksterowicz, Anthony J., and Kristen Paynter. 2000. The Evaluation of the Role and Office of the First Lady: The Movement Toward Integration with the White House Office. The Social Science Journal 37:547-562.

Geer, John. 1996. From Tea Leaves to Opinion Polls: A Theory of Democratic Leadership. New York: Columbia University Press.

Han, Lori Cox. 2004. First Sons versus First Daughters: A Gender Bias in News Media Coverage? In Life in the White House: A Social History of the First Family and the President's House, ed. Robert P. Watson. Albany: State University of New York Press.

Heith, Diane J. 1998. Staffing the White House Public Opinion Apparatus: 1969-1988. Public Opinion Quarterly 62:165-189.

Kelley, Christopher S. 2004. The Tale of Two Brothers: Billy Carter, Roger Clinton, and the Media. In Life in the White House: A Social History of the First Family and the President's House, ed. Robert P. Watson. Albany: State University of New York Press.

Kernell, Samuel. 1997. Going Public: New Strategies of Presidential Leadership, 3rd ed. Washington, DC: CQ Press.

Kinder, Donald R. 1986. Presidential Character Revisited. In Political Cognition, ed. Richard R. Lau and Douglas O. Sears. Hillsdale, NJ: L. Erlbaum Associates.

Neustadt, Richard E. 1990. Presidential Power and the Modern Presidents: The Politics of Leadership from Roosevelt to Reagan. New York: Free Press.

Newman, Brian. 2003. Integrity and Presidential Approval, 1980-2000. Public Opinion Quarterly 67:335-367.

Newman, Brian. 2004. The Polls: Presidential Traits and Job Approval: Some AggregateLevel Evidence. Presidential Studies Quarterly 34:437-448.

Page, Benjamin I., and Robert Y. Shapiro. 1986. Presidents as Opinion Leaders: Some New Evidence. Policy Studies Journal 12:649-661.

Reeves, Thomas. 1991. A Question of Character: A Life of John F. Kennedy. New York: Free Press.

Rahn, Wendy, John H. Aldrich, Eugene Borgida, and John Sullivan. 1990. A SocialCognitive Model of Candidate Appraisal. In Information in Democratic Processes, ed. John Ferejohn and M. Kuklinski. Chicago: University of Chicago Press.

Rose, Richard. 1991. The Postmodern President. New York: Chatham House.

Sullivan, John, John H. Aldrich, Eugene Borgida, and Wendy Rahn. 1990. Candidate Appraisal and Human Nature: Man and Superman in the 1984 Election. Political Psychology 11:459-484.

Troy, Gil. 1997. Affairs of State: The Rise and Rejection of the Presidential Couple Since World War II. New York: Free Press.

Waterman, Richard W., Robert Wright, and Gilbert St. Clair. 1999. The Image-Is-Everything Presidency: Dilemmas in American Leadership. Boulder, CO: Westview.

Watson, Robert P. 2003. Source Material: Toward the Study of the First Lady: The State of Scholarship. Presidential Studies Quarterly 33:423-442.

Whitcomb, John., and Claire Whitcomb. 2000. Real Life at the White House: Two Hundred Years of Daily Life at America's Most Famous Residence. New York: Routledge.

Winfield, Betty H. 1997. The Making of an Image: Hillary Rodham Clinton and American Journalists. Political Communication 14:241-253. 
